\title{
The Indexation of Periodical Payments of Damages in Tort: The Future Assured?
}

\author{
Richard Lewis
}

Professor of Law, Cardiff University

This article examines the new statutory regime for paying damages for personal injury by means of periodical payments instead of a lump sum. How are such payments to increase in future to take account of rising care costs, especially when these usually form the largest part of a major award? The answer to this question is crucial in determining the extent that the new form of payment will be used. How periodical payments are to be indexed is also a key factor in calculating the total cost of compensation, and, in particular, in assessing the liabilities of the National Health Service. The issue gave rise to litigation which was voted by personal injury practitioners as the most important of the year. Here, that litigation and the statutory reforms which gave rise to it are set in their wider academic contexts.

\section{INTRODUCTION}

This article deals with major developments which have taken place in the payment of damages for personal injury. It focuses upon recent judicial decisions which have given much greater incentives for periodical payments to be used instead of traditional lump sums. The benefits are such that periodical payments have now become "the compensation method of choice." This article also describes the new statutory regime for assessing damages for losses which accrue in the future. Placing a value upon these future losses is especially difficult. Determining a discount rate for the lump sum or an index for the future uprating of periodical payments can make an enormous difference not only to the value of an individual claim but also to the overall cost of the tort system. As a result of what may appear on the surface to be small changes in

\footnotetext{
${ }^{1}$ Introduction to R. de Wilde et al, Facts and Figures (London: Sweet \& Maxwell, $13^{\text {th }}$ ed 2008-9).
} 
the numbers used, the liabilities of insurers and, in particular, the National Health Service (NHS) can increase substantially. The focus here is upon the indexation of future loss as a crucial factor in determining not only the value of a claim but also the extent that periodical payments will be used instead of a lump sum. This article describes the wider economic context within which this issue was litigated, and it considers the effect upon personal injury practice of these statutory and judicial changes.

Because the viability of periodical payments under the new statutory regime depends so much upon how future losses are indexed, it was inevitable that the issue would reach the appellate court. In effect, Thompstone $v$ Tameside and Glossop Acute Services NHS Trust ${ }^{2}$ not only determined the future of this new method of payment but also was a case worth many hundreds of millions of pounds a year. ${ }^{3}$ The Court of Appeal found in favour of the claimants, and although appeal to the House of Lords was mooted, it was abandoned. All parties now accept that Thompstone is the keystone upon which settlements are to be based. Practitioners voted it the most outstanding case of the year, ${ }^{4}$ although it received almost no academic recognition. ${ }^{5}$ Academics might have been expected to look at this area closely because it is at the heart of the avowed aim in tort of returning the claimant, so far as is possible, to the financial position before injury. ${ }^{6}$ However, to date, the case has escaped such scrutiny.

${ }^{2}$ [2008] EWCA Civ 5, [2008] 2 All ER 537.

${ }^{3}$ Post Magazine estimated what the cost would be for insurers who had many claims stayed awaiting the decision: "Industry Faces Two Billion Pounds Bill After Appeal Defeat” (2006, August 3) 32.

${ }^{4}$ Personal Injury Awards http://www.personalinjuryawards.co.uk/winners.html

${ }^{5}$ There has been no case note or article in any of the 33 law journals which influence the assessment of academic research as listed by K. Campbell et al, "Ranking of UK Law Journals" (2006) 33 (3) J Law and Society 335 - 363. In contrast, in March 2010 Westlaw noted that there were 51 articles citing the case in the practitioner publications it indexed.

${ }^{6}$ Lord Blackburn in Livingstone v Rawyards Coal Co (1879-80) LR 5 App Cas 25 at 39, reiterated by Lord Hope in Wells $v$ Wells [1999] 1 AC 345, at 390. 
The article begins with a general account of the early development of periodical payments and then summarises the legislative reforms which introduced the new statutory regime in 2005. Next the indexation issue is described, and its potential for causing a substantial shortfall in damages is explained. The litigation on that topic is chronicled, and the factors which enabled the court to select a suitable measure for uprating payments are set out. Finally, the effect of the changes is illustrated by looking at the latest statistics relating to damages paid out by the NHS.

\section{THE INITIAL ATTRACTIONS OF PERIODICAL PAYMENTS}

The lump sum system of paying damages survived almost intact until just over twenty years ago. Compensation almost always took the form of one large payment made on a once and for all basis. It is true that interim awards and provisional damages had made inroads upon this general principle, but the potential for seeking multiple payments was severely limited. Instead the traditional system continued to impose upon claimants an enormous responsibility for their future: they had to manage the lump sum in order to ensure that it would continue to meet their needs for the rest of their life. Unfortunately, inflation and the vagaries of the returns upon investment often resulted in the rapid erosion of the compensation. In addition, the damages were bound to be insufficient where losses continued for a longer period of time than that forecast in the settlement or by the court. This frequently happened where the compensation depended upon an assessment of life expectancy for, if the claimant lived longer than expected, the money was bound to run out. ${ }^{7}$ Recipients of damages awards thus had not only investment but also mortality risks thrust upon them, and often compensation proved insufficient.

To counter such criticisms of the lump sum award, the concept of a structured settlement was imported from North America and first used for a UK resident in

${ }^{7}$ Forecasting how long a seriously injured person will live is notoriously difficult, and actuaries have accepted that estimating what they term an "impaired life" is much more an art rather than a science. R. Lewis, Structured Settlements: The Law and Practice (London: Sweet \& Maxwell, 1993) chapter 11. 
1989. ${ }^{8}$ It enabled seriously injured claimants to receive regular payments which could be guaranteed to last for their lifetime. This was usually achieved by the defendant liability insurer converting part of the traditional lump sum into a series of payments by purchasing an annuity on the claimant's life from a life insurance office. Because of this life element, payments could continue even though a claimant outlived his projected span of years. ${ }^{9}$ In addition, the payments were free of tax, ${ }^{10}$ and could even be set up to enable some claimants to retain entitlement to means-tested benefits even though they were receiving large regular sums. ${ }^{11}$ The payments could also be protected against inflation in prices by being tied to increases in the Retail Prices Index (RPI). ${ }^{12}$ Although this provided much more security for the future, it did not offer protection against the higher inflation to be expected in rising wage costs rather than prices. Nevertheless, claimants receiving structured payments were relieved from the stress of having to invest and be responsible for a lump sum far greater than most

8 Ibid chapter 4. The early history is traced in R. Lewis, "Structured Settlements: An Emergent Study" (1994) 13 Civil J Q 18. See more generally I. Goldrein and M. de Haas (eds), Structured Settlements: A Practical Guide (London: Butterworths, 2nd ed 1997), and for more recent analysis N. Bevan, T. Huckle and S. Ellis, Future Loss in Practice: Periodical Payments and Lump Sums (London: Butterworths, 2007).

9 A. Carus, R. Cropper and V. Wass illustrate the improbability of living to average life expectancy by giving the example of a 40 year old woman who, according to the data, can be expected to live another 47 years. However, the probability that she will die at the exact age of 87 is only 3 per cent. See "Periodic Payments Awards and the Transfer of Risk" in R.J. Thornton and J. Ward (eds) Personal Injury and Wrongful Death Damages Calculations: A Trans-Atlantic Dialogue (2009) 91 Contemporary Studies in Economic and Financial Analysis 159 - 192.

${ }^{10}$ See the Income Tax (Trading and Other Income) Act 2005 s 731 which replaced s 329A of the Taxes Act 1988 .

${ }^{11}$ Social Security Amendment (Personal Injury Payments) Regulations 2002, SI No 2442.

${ }^{12}$ The index measures on a monthly basis the average cost of living by using the prices of a basket of goods and services selected to represent typical the expenditure of consumers. The basket is revised each year to reflect changing trends in such expenditure. Although it was replaced in 1998 by the Consumer Price Index as a key indicator of inflation, the Government continues to use it for the indexation of Index-linked Gilts. 
people encounter in their lifetime. Overall, therefore, they could gain considerable reassurance about their financial future and could plan with greater confidence how to reconstruct their lives.

More detailed accounts of these advantages of structured settlements can be found elsewhere. ${ }^{13}$ It was not only claimants that received the benefits. From the state's viewpoint, the new form of payment was attractive because it encouraged the spending of damages on the purposes for which they had been awarded. The compensation was less likely to be dissipated as a result of mismanagement or the depredation of friends or relatives. ${ }^{14}$ The injured were then less likely to find themselves reliant in the longer term on the limited resources of the welfare state. Structured settlements were especially attractive to the NHS because they enabled Health Authorities to retain capital sums and defer the full costs of clinical negligence to the future: there was a substantial cash-flow saving. Insurers, by contrast, had much less to gain and were therefore often unenthusiastic about structures. However, even they could benefit from appearing to offer lifetime support to an injured person. For a variety of reasons, therefore, structures received support from many quarters.

\section{LEGISLATIVE REFORM AND THE REMOVAL OF THE PARTIES' VETO ${ }^{15}$}

In spite of these benefits, further expansion of structured settlements was hindered by a variety of factors, the most important being the refusal by many lawyers to give proper consideration to the merits of the alternative form of payment. In part, this was

\footnotetext{
${ }^{13}$ R. Lewis “The Merits of a Structured Settlement” (1993) 13 Oxford Journal of Legal Studies 530, Structured Settlements: Report of the Master of the Rolls' Working Party (2002, chairman B.
} Langstaff), paras 6 to 20, and B. Langstaff, "Structured Settlements: Past, Present and Future” [2003] J Personal Injury Law 237.

\footnotetext{
${ }^{14}$ See, for example, The Times, March 9, 2000, "Father used Half of Son’s £400,000 Payout."

${ }^{15}$ R. Lewis, "The Politics and Economics of Tort Law: Judicially Imposed Periodical Payments of Damages" (2006) 69 Modern Law Rev 418 - 442.
} 
attributed to the innate conservatism of the legal profession, ${ }^{16}$ together with ignorance or misconception about what the periodical payments actually involved. Although for some years it was emphasised that lawyers had a duty to consider setting up a structured settlement and could be liable in negligence if they failed to do so, ${ }^{17}$ in practice periodical payments were obtained in only a minority of the cases in which they could have been sought. ${ }^{18}$

The result was that, largely through inertia, the lump sum retained its dominance. This was aided by the fact that either of the parties unilaterally could veto any proposed settlement based on periodical payments. ${ }^{19}$ According to Lord Steyn the solution was straightforward:

16 “... lawyers and litigants are innately conservative, were wholly familiar with lump sum compensation and instinctively distrustful - and probably unfamiliar with - newfangled devices such as structures.” W. Norris QC, "Structured Settlements: Past and Future Developments" paper delivered to the Legal Wales Conference, September, 2003.

${ }^{17}$ R. Lewis, “A Lawyer's Duty to Consider a Structured Settlement” (1993) 9 (3) Professional Negligence 126. See similarly the warning given to today's lawyers by N. Bevan, "Future Proof" (2008) 158 New LJ 116: "Those who continue to turn a blind eye or otherwise fail to advise their clients on periodical payments expose themselves to a very real risk of facing a professional negligence claim in years to come, as and when the money runs out."

${ }^{18}$ For example, in 2001 - 02 the NHS paid over 500 claims in excess of $£ 100,000$ and yet less than ten per cent involved a structured settlement according to the Lord Chancellor's Department, Courts Bill: Regulatory Impact Assessment (November, 2002) table 1. For cases involving clinical negligence and dealt with by the Court of Protection in 2004 - 05 the take up was slightly higher, amounting to just over 26 per cent of the total according to a personal communication to the author from Denzil Lush, Master of the Court of Protection. Overall about 1500 structures were put in place for all types of injury between 1988 to 2006 .

${ }^{19}$ The need for the consent of both parties was affirmed as early as Burke v Tower Hamlets (1989) The Times, August 10, [1989] CLY 1201. The point was reinforced by $R v$ Liverpool Health Authority et al ex parte Hopley [2002] All ER 459 discussed in R. Lewis, "Clinical Negligence and the NHS Refusal to Structure Settlements With Profit” (2003) 19 Professional Negligence 297. 
"The court ought to be given the power of its own motion to make an award for periodic payments rather than a lump sum in appropriate cases.... Except perhaps for the distaste of personal injury lawyers for change of a familiar system, I can think of no substantial argument to the contrary. Only Parliament can solve the problem." 20

There followed a lengthy period of investigation ${ }^{21}$ and Government consultation ${ }^{22}$ about what changes should be made. Eventually, in 2005 legislation came into force which removed the parties' veto: under the Courts Act a judge was given the power to impose a periodical payments order (PPO) even if it were opposed by both parties. ${ }^{23} \mathrm{~A}$ former President of the Association of Personal Injury Lawyers rather expansively concluded that the legislation was "the most important development ever relating to the law of damages." 24 It was certainly of great significance for it introduced a radically different method not only for paying damages but also for assessing them.

${ }^{20}$ Wells $v$ Wells [1999] AC 345 at 384.

${ }^{21}$ The Clinical Disputes Forum Discussion Paper, Lump Sum Damages and Periodical Payments (2000) and the report summarising the responses (April 2002). An important contribution was made by the Master of the Rolls Working Party, Structured Settlements (2002), as discussed by its chairman Brian Langstaff in "Structured Settlements: Past, Present and Future" [2003] J Personal Injury Law 237.

${ }^{22}$ Lord Chancellor's Department, The Discount Rate and Alternatives to Lump Sum Payments (Consultation Paper 3/00, March 2000), Lord Chancellor's Department, Damages for Future Loss (Consultation Paper CP 01/02, March 2002), and its Analyses of the Responses (CP (R) 01/02, November 2002). The Department also published in November 2002 the Courts Bill: Regulatory Impact Assessment on that aspect of the legislation which dealt with the power to order periodical payments.

${ }^{23}$ Courts Act 2003 s100 and 101 amending the Damages Act 1996 and coming into force in April 2005.

${ }^{24}$ Colin Ettinger (2005) 155 New LJ 525. See similarly the London International Insurance and Reinsurance Market Association, Third UK Bodily Injury Awards Study (London: International Underwriting Association of London, 2003) 83 describing the Courts Act as producing "the most fundamental change in 150 years in the quantification of bodily injury claims involving continuing losses." 
The new regime applies to any personal injury case which comes to court and involves future pecuniary loss. The statute then requires a judge to consider making a PPO. The needs of the claimant must be considered, but an order can be made even if it is not wanted by either of the parties and even though they both envisage alternative provision. Almost all cases which come to court are likely to be caught by the statute because they predominantly involve serious injury with a substantial part of the claim being for future loss. ${ }^{25}$ The major constituent will be for the cost of future care, although loss of earnings will also play a part. Although these serious injury cases are only a small percentage of all personal injury claims, ${ }^{26}$ they are responsible for a substantial amount of the overall damages bill: insurers have estimated that 32 per cent of the monies they pay to claimants derive from only one per cent of their cases, these being where damages of more than $£ 100,000$ are paid. ${ }^{27}$ In spite of the large sums involved, it is more likely in these serious injury cases that claimants will be under-compensated in the longer term. ${ }^{28}$ It was for these claimants, in particular, therefore, that the new method of assessment and payment was introduced, and it was for them that the issue of indexation would prove so important.

${ }^{25}$ For example, it was estimated that, on average, 83 per cent of a claim exceeding $£ 250,000$ against the NHS comprised future loss. Lord Chancellor's Department, Courts Bill: Regulatory Impact Assessment (November 2002) table 3. Future loss in other than clinical negligence cases is less prominent as revealed by table 8 of the same Assessment in which the Association of British Insurers estimated that it constituted only 46 per cent of the value of claims between $£ 100,000$ and $£ 250,000$.

${ }^{26}$ The preponderance of small claims in the system is reflected in the fact that non-pecuniary loss accounts for about two thirds of the overall damages bill and past financial loss for about a further quarter. See the Report of the Royal Commission on Civil Liability and Compensation for Personal Injury (1978, cmnd 7054), chairman Lord Pearson (the Pearson report) vol 2 para 107.

${ }^{27}$ Lord Chancellor's Department, Courts Bill: Regulatory Impact Assessment (November 2002) table 1.

${ }^{28}$ R. Lewis, R. McNabb and V. Wass, "Court Awards of Damages for Loss of Future Earnings: An Empirical Study and an Alternative Method of Calculation” (2002) 29 J of Law \& Society 406 and [2002] J of Personal Injury Law 151 and, by the same authors, "Loss of Earnings Following Personal Injury: Do the Courts Adequately Compensate Injured Parties?” (2003) 113 Economic Journal 568. 


\section{“BOTTOM-UP” ASSESSMENTS AFFECTING INVESTMENT AND LIFE EXPECTANCY RISKS}

The tradition in damages is for there to be a clean break, with the defendant giving the claimant a once and for all payment to end matters. In contrast, a structured settlement or a court ordered PPO results in a continuing relationship between the parties with payments that will vary over time. However, the Courts Act made the distinction between the different forms of payment very much greater by conferring upon PPOs particular advantages over the previous ways in which damages were paid. The Act not only fundamentally changed the way in which damages are assessed, but it also offered claimants considerable incentives to seek PPOs rather than lump sums. PPOs were also given advantages over structured settlements negotiated out of court.

The key distinguishing feature of a PPO is that, unlike nearly all structures, there is no need to calculate any lump sum in order to work out what periodical payments must be made. Instead, using a "bottom-up" approach, the court assesses the periodical payments the claimant needs for the future irrespective of their capital cost. These annual payments do not have to be adjusted to take account of speculative estimates of the claimant's life expectancy. Nor do returns have to be forecast of the income that arises upon investment of the damages: the lump sum is not there to invest. Instead, the defendant must comply with the order to make the specified regular payments no matter how the market performs and even if the claimant lives longer than forecast. In contrast to the traditional lump sum system, therefore, it is the defendant rather than the claimant who is exposed to an uncertain financial future by being burdened with the twin risks of investment return and mortality.

This can be explained further by noting that in the calculations needed for a PPO there is no place for the 'Ogden Tables. ${ }^{, 29}$ That is, multipliers and discount rates are not used: no multiplier is required to reflect the period of years of the loss in order to convert it into an immediate capital amount; and no discount rate is needed to convert

\footnotetext{
${ }^{29}$ Government Actuary's Department, Actuarial Tables For Use In Personal Injury And Fatal Accident Cases (London: The Stationery Office, $6^{\text {th }}$ ed 2007).
} 
the future stream of financial losses into a capital sum representing present day values. The discount rate, in particular, continues to operate very harshly against claimants negotiating lump sums. ${ }^{30}$ This is because it expects claimants to obtain an unrealistic rate of return on their damages award. However, when PPOs are being considered, defendants cannot take advantage of the artificially high estimate of investment return embedded in the discount rate for lump sums. Instead they can be ordered to provide annual payments irrespective of what this might cost as an equivalent capital sum. Furthermore, the order extends for an uncertain period - the rest of the claimant's life. The risks of uncertainty traditionally run by claimants have thus been transferred to defendants.

\section{THE INDEXATION ISSUE AND THE POTENTIAL SHORTFALL IN PAYMENTS}

In spite of the considerable advantages offered by PPOs as a result of this transfer of the mortality and investment risks there was still concern that new form of payment might not be widely used. For almost three years after the Courts Act came into force it was thought that the lump sum might be more flexible, and better able to deal with the claimant's needs. This argument succeeded in a number of cases with the result that, although PPOs were being considered, ultimately they were often rejected. Why

\footnotetext{
${ }^{30}$ See the comments of the former Government Chief Actuary, Chris Daykin, "From Lump Sums to Periodical Payments and Beyond" (2005) a paper presented to a conference at the Institute of Actuaries, March 2005, and by the same author, "Fair Compensation Needs Actuaries" [2009] J Personal Injury Law 48 - 65. As noted in an introduction to the Government Actuary's Department, Actuarial Tables For Use In Personal Injury And Fatal Accident Cases (London: The Stationery Office, $5^{\text {th }}$ ed 2004) para 15 , the set discount rate has never been within 0.5 per cent of the correct rate of return. The effect of this is illustrated in the introduction to R. de Wilde et al, Facts and Figures (London: Sweet $\&$ Maxwell, $13^{\text {th }}$ ed 2008 - 9). To achieve full compensation a discount rate of at most $1 \%$ and not $2.5 \%$ should be applied. This would substantially increase lump sum payments. For example, for a ten year old with normal life expectancy requiring modest care costs of $£ 10,000$ a year, the lump sum needed would increase from $£ 337,000$ to $£ 527,000$. In effect, the lower lump sum presently awarded will fund payments of only $£ 6,400$ a year instead of the $£ 10,000$ actually required. Similar calculations are made by N. Martin, "Periodical Payments" (2009) 106 (24) Law Soc Gazette 22 and E. Tomlinson, "Budgeting on a Lump Sum Settlement” [2009] J Personal Injury Law 164.
} 
were claimants' lawyers and courts having doubts about the efficacy of judicial "bottom-up" assessments which transferred the above risks? The answer lay in concern about exposing the claimant to another risk: this was that the periodical payments would not offer sufficient protection against anticipated increases in care costs because these were more affected by wage rates rather than prices. Although protection against price increases could be guaranteed, protection against wage increases could not. Whether it could be achieved depended on how payments were to be indexed. This was crucial to the future use of periodical payments.

Periodical payments have the advantage of providing certainty of provision for life. However, unless they are linked to an appropriate index the certainty they achieve may become the certainty of under-provision. The concern was that, even if periodical payments were tied to increases in the RPI, they would be insufficient to meet the claimant's future needs. This is because home care costs make up only about one tenth of one per cent of the RPI, and they have only a limited relationship with increases in the price of those consumer goods and services which dominate the index. Most future losses of personal injury claimants are directly or indirectly related not to price increases but to earnings. In particular, a very large element of future care costs is dependent upon the earnings of those workers who provide the care: in the leading case the non-earnings element of care was expected to be only three per cent of the total care costs. ${ }^{31}$ Historically, on average, for the past seventy years the earnings of the population at large has risen about two per cent more a year than prices. ${ }^{32}$ Claimants and their advisors therefore feared that if this general trend were also to apply to care workers, then any award of periodical payments based on the RPI would

${ }^{31}$ Thompstone v Tameside and Glossop Acute Services NHS Trust [2008] EWCA Civ 5 para 107.

${ }^{32}$ Government Actuary's Department, Actuarial Tables For Use In Personal Injury And Fatal Accident Cases (London: The Stationery Office, $5^{\text {th }}$ ed 2004) (The Ogden Tables) Appendix A para 12: "Real earnings growth ... has averaged 1.5 to 2 per cent a year more than growth in the RPI." Although there have been years, such as 1995 and 2007, when the rise in prices exceeded that in earnings, the evidence presented in Thompstone was that between 1998 and 2005 earnings outpaced the RPI by $1.73 \%$ a year, and the earnings of care workers in particular outpaced the RPI by $2.84 \%$ a year. 
prove insufficient to meet long-term care needs. ${ }^{33}$ Indeed, it is likely that the difference between indexation based upon price as opposed to wage inflation will be apparent in the very first year in which care is provided. The obvious disparity between the payments led the judge to refuse to make a PPO in, for example, $A v B$ Health Hospitals NHS Trust. ${ }^{34}$ It was thought that the claimant would be better off with the flexibility of a lump.

To illustrate the potential for under-compensation let us assume that the claimant obtains a periodical payment award of $£ 10,000$ a year to cover future care costs. If the award were linked to the RPI and if that index rose by, say, 2.5 per cent a year then, after 30 years, the amount being paid would be $£ 20,975$. However, if the award were indexed to reflect earnings growth at 2 per cent above RPI, the amount to be paid would rise to $£ 37,500$ a year. The cumulative deficit over the 30 year period would then be $£ 171,000$ and the claimant would be receiving insufficient to meet his current costs. The deficit resulting from the difference between prices and earnings would continue to grow, and the support given to the claimant would continue to diminish. ${ }^{35}$ The capital value of the difference between the indices is a substantial sum: a two per cent difference over 40 years will cost defendants an extra $£ 200,000$ in immediate lump sum terms for each $£ 10,000$ a year required. In one recent case the cost of the private nursing home was $£ 132,000$ a year and this was projected to last another 48 years. ${ }^{36}$ If an earnings index were used in this case it would have increased the lump

${ }^{33}$ As illustrated in R. Hogg, "Will Periodical Payments Provide Adequately for the Costs of Care?" [2004] J Personal Injury Law 209. Contrast W. Norris, "Periodical Payments: Indexation, Variation, Protection and Practice" [2005] J Personal Injury Law 59 with a reply by R. de Wilde at [2005] J Personal Injury Law 147.

${ }^{34}$ [2006] EWHC 2833 (Admin), [2007] LS Law Medical 303, (2007) 95 BMLR 240, applied in Thorp v Hunt [2007] CLY 3081. In part, the decision was based on the prospect of the lump sum attracting high investment returns. It was particularly unfortunate that shortly thereafter the stock market lost a third of its value.

\footnotetext{
${ }^{35}$ As also illustrated by R. Hogg op cit above note 33 at 213.

${ }^{36}$ Peters v East Midlands Strategic Health Authority [2009] EWCA Civ 145, [2009] 3 WLR 737.
} 
sum required by more than $£ 3$ million. The NHS is considerably affected by such indexation because it has a disproportionate number of these complex and expensive care cases.

There are two examples of notable past cases which further illustrate how periodical payments could prove insufficient to meet the increasing costs of care. ${ }^{37}$ The first case is of some prominence because originally it had come before the Court of Appeal to determine whether certain social security monies could be claimed even though substantial structured settlement payments were being received. ${ }^{38}$ It involved Charles Beattie who was only 17 years old in 1987 when he suffered severe brain damage and was made quadriplegic as a result of a car accident. Five years later he obtained a million and a half pounds in damages. Some of this money was used to meet his immediate needs, and some was placed in a contingency fund to deal with unexpected future requirements. The remaining million pounds was paid into a structured settlement to fund his current care costs. This produced RPI linked payments of more than $£ 5,000$ a month, as well as payments of $£ 10,000$ every three years to cover the purchase of specialised equipment. However, the Master of the Court of Protection has revealed that these payments have proved insufficient. ${ }^{39}$ In the twelve years following the court award, although the RPI linked payments rose by 35 per cent, the cost of care rose by 60 per cent, this being roughly in line with the growth in average earnings. As a result, Charles Beattie cannot pay for the full package of care that he needs from the income he receives from his structured settlement.

${ }^{37}$ See also P. Cane, Atiyah's Accidents, Compensation and the Law (London: Butterworths, $7^{\text {th }}$ ed 2006) 160 where the problem is illustrated by reference to a leading Australian case.

${ }^{38}$ Beattie v Secretary of State for Social Security [2001] EWCA Civ 419, L1 Rep Med 297 noted in (2002) 9 J Social Security Law $43-49$

${ }^{39}$ D. Lush, "Damages for Personal Injury: Why Some Claimants Prefer a Lump Sum to Periodical Payments" (2005) 1 (2) London Law Rev 187 at 192. In addition, the contingency fund that was set up was exceptionally low and has now been exhausted. 
The second case to illustrate the potential shortfall is the landmark decision from twenty years ago of Kelly $v$ Dawes. ${ }^{40}$ This was the first case in which a judge approved a structured settlement for a U.K. resident. Catherine Kelly, a 22 year old nurse, was a passenger in a car driven by her husband, Andrew, a stonemason. Not far from their home they were involved in a road accident caused entirely by the negligence of another. Both drivers were killed. Catherine lost the husband she had recently married, and suffered catastrophic injuries herself. In seeking damages on her behalf, Catherine's father was keen to ensure that she would be looked after in her private nursing home for the rest of her life. Any money that might accrue to her estate upon her death was not an important consideration. Instead the major concern was that, given her very uncertain life expectancy, the damages should be managed in order to ensure that, if she lived longer than the projected period, there would continue to be money to pay for her care. The best means of achieving this proved to be via a structured settlement which, because it could be linked to a life annuity, could be guaranteed to be in payment for the rest of Catherine's life.

Catherine's settlement undoubtedly has proven a favourable one for her. She continues to receive payments even though she has now outlived not only the pessimistic life expectancy relied upon by the defendant insurers, but also the compromised figure that would have been agreed by the parties had only a lump sum been paid. As a result of the structure, her family gained the reassurance that she would continue to be looked after for the rest of her life. Payments for her began at $£ 2,146$ a month but were to rise in line with the RPI. As a result, they increased on average by about 3.1 per cent a year and amounted to just over $£ 4,000$ a month in 2009. However, it has recently been revealed that these payments have been

40 (1990) The Times, $27^{\text {th }}$ September. Its history is discussed in Lewis op cit above note 8 and by I. Goldrein, M. de Haas and J. Frenkel, Personal Injury Major Claims Handling: Cost Effective Case Management (2000) para 17.168. For an updated account see R. Lewis, "Tort Law in Practice: Appearance and Reality in Reforming Periodical Payments of Damages” at 488 et seq in J. W. Neyers et al (eds), Emerging Issues in Tort Law (Oxford: Hart Publishing, 2007). 
"considerably outstripped" by the present nursing home care costs. ${ }^{41}$ The shortfall is currently being met out of her contingency fund. This capital sum derived, firstly, from the equity in Catherine's home which was sold because she could no longer live there and, secondly, from the estate she inherited from her husband, including the damages for his fatal accident. Although the case illustrates how RPI linking can lead to under-compensation, it should be emphasised that at the date of settlement this problem had not been recognised and that it was not until the new millennium that the effect of RPI linking on future care costs was called into question. Even if the issue had been aired in 1989, it is likely that the life expectancy aspect would have persuaded the court that periodical payments, although RPI linked, were in Catherine's best interests.

\section{THE INDEXATION LITIGATION}

What provision did the Courts Act make for the indexation of the new periodical payments regime it established? Although it made RPI the default index for PPOs, it also allowed for that index to be modified or replaced. ${ }^{42}$ This caused much uncertainty because the legislation did not specify when it would be appropriate to make such a departure from RPI. In Parliamentary debates on the Courts Bill the Minister, Baroness Scotland, said that it was intended that RPI should be the norm, but that it could be departed from "in exceptional circumstances." ${ }^{43}$ Although this phrase was also contained in a first draft of the Explanatory Notes to the Courts Act, it was later revised to refer only to "appropriate" circumstances, and again these were not defined. In the final version of the Notes the guidance is only that it is expected that RPI will be used in the great majority of cases. ${ }^{44}$

\footnotetext{
${ }^{41}$ S. Ashcroft, "From Kelly to Courts Act - The Development of Periodical Payments" [2009] J Personal Injury Law 191.

${ }^{42}$ Damages Act 1996 s 2 (8) and (9) as amended by the Courts Act 2003 s 100.

${ }^{43}$ HL Deb vol 648 col 536 - 7 (May 19, 2003).

${ }^{44}$ Paragraph 354.
} 
The Government's failure to give clear guidance, only partly the result of a Minister inexperienced in personal injury matters, was very unfortunate. Litigation was the inevitable result. The first case was a pre-emptive attack by one insurer seeking to strike out the claimant's pleading that there should be a departure from the RPI. The insurer contended that "exceptional circumstances" were required. Many defendants did not support this tactic of challenging the claimant's case in a preliminary hearing when the burden upon the party seeking the order is higher. In particular, the NHS Litigation Authority was not a party to the action. Reservations about the tactic proved well merited: both at first instance and before the Court of Appeal the attempt to prevent departure from RPI because there were no exceptional circumstances failed. In Flora $v$ Wakom $^{45}$ the claimants had won the first round.

However, the Court of Appeal in Flora also suggested that further cases should be grouped together and brought before it so that it could examine the issue of indexation in a full hearing. Eventually this was done in the key case of Thompstone $v$ Tameside and Glossop Acute Services NHS Trust. ${ }^{46}$ In fact only four cases were heard together, and unlike in the striking out action, it was the NHS Litigation Authority rather than insurers that took the case forward. It had to act alone because, according to its counsel, insurers "expressed little interest in these appeals." ${ }^{47}$ Insurers may either have feared that their case had already been fatally compromised by the Flora decision, or may have mistakenly believed that they could buy off the prospect of PPOs by offering claimants larger lump sums instead. At all events, the defendants were not co-

${ }^{45}$ [2006] EWCA Civ 1103, [2007] 1 WLR 482. Similarly claimants succeeded in the other first instance cases of Sarwar v Ali [2007] EWHC 1255 (QB), Corbett v South Yorkshire Strategic Health Authority [2007] LS Law Medical 430 and RH v United Bristol Healthcare NHS Trust [2007] EWHC 1441 (QB), these last two cases forming part of the conjoined appeals in Thompstone.

${ }^{46}$ [2008] EWCA Civ 5, [2008] 2 All ER 537.

\footnotetext{
${ }^{47}$ Philip Havers, "Periodical Payments" paper presented at the Future Loss in Practice conference, the London Stock Exchange, 24 April 2008. He also commented that "the whole exercise had, from the Appellants' point of view, got off to a very unfortunate (and some would say misguided) start in ... Flora." As a result, in Thompstone counsel "had to argue the issues of law effectively with one arm tied behind our backs."
} 
ordinated in their attempts to limit the effect of the new legislation, and they seemed to have considerable doubts about whether their arguments would prevail.

These reservations proved to be well founded when, both at first instance and on appeal, the claimants once more triumphed. The Court of Appeal considered itself bound by the previous decision in Flora to reject the submission that exceptional circumstances were needed to depart from the RPI. In addition, the Court recognised that PPOs created a quite different payment mechanism from lump sums so that, in effect, two separate regimes were now operating within the tort system. It rejected the suggestion that there would be "an unacceptable divergence" if a wage related index were used for PPOs and a price related index for lump sums. However, it cannot be disputed that a divergence arises. It is created because the traditional lump sum, unlike a PPO, calculates a present value for the claimant's future losses by using a discount rate set at 2.5 per cent. This rate, in theory, is supposed to represent the real return the claimant can obtain by investing the damages received. ${ }^{48}$ This real return makes allowance both for the tax the claimant must pay on the income from investing the damages and for the reduction in the value of that income caused by inflation. However, the rate takes into account only the inflation in prices, not that in wages. This was confirmed in Cooke $v$ United Bristol Healthcare ${ }^{49}$ where the court steadfastly refused to depart from price inflation when assessing the lump sum. Here, then, is clear water between the methods used to allow for inflation when calculating a lump sum as opposed to a PPO, the one being based on prices, the other on earnings.

Finally, the judges in Thompstone also rejected arguments against the use of an earnings index which were based on "distributive justice." Defendants reasonably feared that this index would lead to much higher payments with the result that the NHS, in particular, would be adversely affected. An actuary giving evidence on behalf of the NHS argued that the increase in value for clinical claims already in existence would be $£ 1.678$ billion. Although the trial judge rejected this as a significant over-

\footnotetext{
${ }^{48}$ For criticism see above note 30.

${ }^{49}$ [2004] 1 All ER 797.
} 
estimate because it was based on a flawed empirical study, she agreed that the increase in cost would be "very significant." ${ }^{, 50}$ In the past there had been limited evidence that NHS wards might have to be closed in order to pay for damages awards. ${ }^{51}$ However, these arguments, based on the wider social benefit of retaining existing damages levels, were considered irrelevant by the Court of Appeal. It conceded that distributive justice might be relevant when considering whether a duty of care was owed, or whether the general level of damages for non-pecuniary loss was appropriate. However, distributive justice was said to have no part to play after liability had been established when the only remaining issue was the calculation of precise financial losses, as opposed to general damages for pain and suffering. ${ }^{52}$ Overall, the claimants thus far had won a resounding victory of principle, but what would it mean in practice?

\section{WHICH METHOD OF INDEXATION?}

Although there were these strong arguments of principle for departing from the RPI, there were practical difficulties in setting an alternative. ${ }^{53}$ Was there another index that could be used? If not, as in the case of a claimant resident in Ireland where no appropriate index could be identified, ${ }^{54}$ then perhaps only RPI linking or a lump sum could be awarded. One alternative suggestion was that a fixed percentage above the RPI should be used, but this rough and ready solution never formally came before

${ }^{50}$ Swift J in Thompstone v Tameside and Glossop Acute Services NHS Trust [2006] EWHC 2904 para 71.

${ }^{51}$ R. Dingwall et al, Medical Negligence: A Review and a Bibliography (Oxford: Centre for SocioLegal Studies, 1991) 55.

${ }^{52}$ Thompstone v Tameside and Glossop Acute Services NHS Trust [2008] EWCA Civ 5, [2008] 2 All ER 537 para 47.

${ }^{53}$ V. Wass, “The Indexation of Future Care Costs” [2007] J Personal Injury Law 247 - 261.

${ }^{54}$ In A v Powys Local Health Board [2007] EWHC 2996. 
a court. ${ }^{55}$ Another possibility was to use earnings indices that were being employed elsewhere. However, these alternative measures were not being used by lawyers or courts. In addition, they produced figures which could vary significantly. For example, different earnings figures could be derived from the likes of, firstly, local authority based rates of pay for carers; secondly, the British Nursing Association recommended rates for carers; thirdly, indices used to manage health care efficiency; ${ }^{56}$ and, finally, Government figures of average earnings for different sections of the workforce. Some of these alternative indices were officially compiled by state agencies, others came from private bodies; some had a longer history or were more consistently produced than others; and some were able to look more precisely at particular sections of the workforce. Because each set of figures was open to some criticism, there was no immediately obvious alternative index that could be used.

An academic labour economist, Dr Victoria Wass of Cardiff University, had a major influence on the Court in determining which path to take. She was described by the trial judge as "an impressive witness." 57 The Court of Appeal accepted the following criteria that she suggested for adopting an alternative measure to RPI which would approximate to the salary-based costs of home care:

"(i) accuracy of match of the particular data series to the loss or expenditure being compensated;

(ii) authority of the collector of the data;

(iii) statistical reliability;

(iv) accessibility;

(v) consistency over time;

55 The suggestion came from R. Hogg op cit and from the Association of Personal Injury Lawyers, Periodical Payments: An Assessment of Concerns and Solutions (March 2004). Although Hogg presented the idea in evidence, it was not considered or tested in Cooke v United Bristol Healthcare Trust [2003] EWCA Civ 1370, [2004] 1 WLR 251.

\footnotetext{
56 These include a pay cost index and a health services cost index. L. Curtis, Unit Costs of Health and Social Care 2008 (Canterbury: University of Kent, 2009). http://www.pssru.ac.uk/uc/uc.htm

${ }^{57}$ Swift J in Thompstone v Tameside and Glossop Acute Services NHS Trust [2006] EWHC 2904 para 77 cf Nicholas Bevan who describes Wass as the "doyenne of labour economists" in "Future Proof" (2008) 158 New LJ 1168.
} 
(vi) reproducibility in the future;

(vii) simplicity and consistency in application., ${ }^{, 58}$

Using these factors, Wass concluded that the Court should choose between two official earnings data sources, one being the Average Earnings Index (AEI) and the other the Annual Survey of Hours and Earnings (ASHE). Both are produced with the authority of the Office of National Statistics, the first dating back to 1963 and the second, only to 1998 .

The AEI plots average earnings growth by surveying each month the payments made by 8,400 employers to about 9 million employees. It takes into account bonuses, allowances and overtime to arrive at an average earnings figure. However, the Court rejected the use of this index because, although long established, accessible and well known, the information it provides is too general. In particular, it does not relate to particular employments. Instead it is based on the mean level of earnings for all workers and, crucially for present purposes, it does not directly relate to the earnings of the one in 40 employees who work as carers. Their earnings are likely to be lower than average and, as a result, if the AEI were to be used it would probably overstate the claimant's future care needs. Instead of using this index the Court adopted the more precise measure of earnings contained in the more complex ASHE data because it could be related to specific occupations.

Like the AEI, ASHE is based on a representative survey of earnings and appears as a statement of earnings levels instead of a numerical index such as the RPI. At first it may appear less useful than AEI because fewer people are surveyed and the data is collected less frequently: the survey takes place only once a year as opposed to once a month, and it covers only about one per cent of those employees paying tax on a payas-you-earn basis, these numbering about 245,000 workers. However, ASHE data has become increasingly more sophisticated. Its crucial advantage over the AEI is that it can be sub-divided to account for different occupational groups and different levels of earnings within occupational groups.

\footnotetext{
${ }^{58}$ Thompstone v Tameside and Glossop Acute Services NHS Trust [2008] EWCA Civ 5, [2008] 2 All ER 537 at para 75.
} 
The important group for present purposes is that numbered 6115 comprising "Care Assistants and Home Carers." There were 6,630 employees who fell into this group to constitute the representative sample in 2006. ASHE reflects the specific factors which have affected individual groups so that, for example, it is apparent that the earnings of care assistants in the last decade have risen much faster than average earnings overall. In addition, the specific data for the occupational group can be further subdivided into ten parts according to their hourly rate of pay. This enables separate tracking of the earnings of the more skilled carers who are likely to be placed at the top of the earnings scale. As a result it is now common to see a PPO tied, for example, to the $70^{\text {th }}$ percentile of ASHE 6115 (where 30 per cent of carers earn more than that rate and 70 per cent less). Which exact percentile is to be used in a particular case depends upon which is nearest to the weighted average hourly rate of pay of the different carers in the overall package which has been specifically designed for the claimant. This weighted rate of pay thus depends upon the complexity of care provided in each case. Potentially this can be a difficult and controversial calculation because it will include different rates of pay for day, night and weekend work, as well as different rates for the levels of experience and skill of the carers. Defendants can be expected to examine such calculations closely and readily contest them.

Arguments about the weighted rate of pay for the different carers and the hours that they work illustrate that there is still scope for dispute. However, the Court has tried to limit other disagreements by discouraging certain lines of attack. Having accepted that the appropriate measure for the test cases before them was ASHE 6115, the Court of Appeal was not prepared for that issue to be re-opened in later cases unless substantially different evidence and new arguments were produced. Judges were instructed to have no hesitation in striking out attempts by the parties to do otherwise. Similarly, the Court was against defendants calling their own expert evidence to show that a PPO does not best meet the claimant's needs. ${ }^{59}$ Finally, in order to make the ASHE 6115 data more easily workable, a model Schedule to the PPO was approved for the many cases which had been among those stayed to await the Thompstone

\footnotetext{
${ }^{59}$ Ibid para 112.
} 
ruling. ${ }^{60}$ Again practitioners were warned that courts would make it difficult for them to depart from this Schedule. As a result of these measures one judge hoped that " $[t]$ he armies of experts will then be able to strike their tents and return to the offices or academic groves from which they came." ${ }^{, 61}$ Although this may happen with regard to the principle of indexation, the assistance given by experts on the facts of specific cases will not diminish. Their employment in a wide variety of personal injury contexts has continued at an increasing pace, and is a very distinctive feature of such litigation today compared even to the recent past.

\section{INDEXATION OF FUTURE LOSSES OTHER THAN CARE}

If departure from RPI is justified to take account of earnings when assessing care costs, it appears logical to extend the argument to the calculation of damages for the loss of future earnings themselves. At present the claimant's lump sum damages are frozen at the date of trial or settlement, and no allowance is made for the anticipated rise in the standard of living which all workers are expected to enjoy in the future. ${ }^{62}$ Of course, allowance is made for the higher wages resulting from prospects of promotion, but not for the increases that might be expected because of the rise in living standards. This seriously limits the size of the lump sum award, ${ }^{63}$ and gives the lie to the avowed aim of returning the claimant to the pre-accident position.

However, in periodical payment cases claimants will now be able to enjoy future increases in the standard of living because in Sawar $v A l i^{64}$ the court ordered that a

\footnotetext{
${ }^{60}$ The NHS alone had 104 cases awaiting the Court of Appeal decision. The Schedule was approved by Mackay J in RH v United Bristol Healthcare Trust [2008] EWHC 2424, and was modified by Holland J in Thompstone v Tameside Hospital NHS Foundation Trust [2008] EWHC 2948, [2009] PIQR P9.

${ }^{61}$ Brooke LJ in Flora v Wakom [2006] EWCA Civ 1103 para 33.

${ }^{62}$ P. Cane, Atiyah's Accidents, Compensation and the Law (London: Butterworths, $6^{\text {th }}$ ed 1999) 133.

(The analysis is omitted from the current edition).

${ }^{63}$ For examples of its effect see R. Lewis, R. McNabb and V. Wass op cit above note 9.

${ }^{64}[2007]$ EWHC 1255.
} 
suitable earnings index rather than RPI should be used to uprate the payments. In this case Waseem Sarwar, a 17 year old passenger in a car, was rendered tetraplegic as a result of the driver's negligence. In spite of his very serious injuries, he was expected to live to the age of 72 . He would need extensive full time care. In lump sum terms and before a 25 per cent discount was applied for failing to wear a seatbelt, the judge valued the case at over $£ 9.5$ million. He decided that, although the claimant had yet to sit his A level examinations, he would have obtained a professional qualification and relatively high earnings. He forecast that Waseem would have been employed in the field of finance, economics or accountancy. All four financial experts in the case agreed that it would be inappropriate to use the RPI to compensate for the future loss of earnings. Instead the judge awarded periodical payments linked to the $90^{\text {th }}$ percentile of the aggregate figure for ASHE. That is, he forecast that Waseem would have been in the top ten per cent of all earners. The case is typical of serious injury cases in that Waseem's lost earnings comprised only about 10 per cent of the total award, whereas more than 50 per cent of the award was for future care costs. For both types of loss the judge ordered periodical payments linked to ASHE. He did so even though the claimant changed his mind at the last minute and expressed a wish for all his compensation to be paid in one lump sum. This request was refused because the expert evidence was compelling in favour of most of the compensation being paid via periodical payments. As a result, Waseem was left with a lump sum of less than a quarter of the size that he would otherwise have received. The case illustrates several important features of the new regime, but for present purposes its key point is that earnings losses as well as care costs can be subject to higher indexation.

How should other heads of future loss be indexed? Sums for the supply of equipment, aids to mobility, transport and so on have been indexed in line with the RPI, although there are arguments that the technological advances in rehabilitation are not only proceeding rapidly but also at a cost that makes the RPI no longer appropriate. In addition, there are doubts about how to index the running costs of accommodation, and how to deal with Court of Protection costs, especially following their increase by the Mental Capacity Act 2005. It is also unclear to what extent the cost of certain treatments or therapies should be tied to an earnings index. However, overall these uncertainties are relatively minor now that it is clear that both the future 
cost of care and the loss of earnings are no longer subject to the limit of RPI indexation.

\section{THE EFFECT UPON THE NHS}

Although the full effects of Thompstone have still to be worked out, its significance can be assessed by looking at the impact it has already made upon claims against the NHS. The NHS has favoured the use of periodical payments for many years. ${ }^{65}$ One reason for this is that, unlike many insurers, the NHS has been able to self-fund such awards, thereby ensuring that it can defer large capital payments to later years. PPOs provide a means of paying for today's injuries tomorrow. The NHS Litigation Authority has stated that even after the adverse decision in Thompstone, it will continue to encourage the use of periodical payments because it considers "them to be the fairest method, both for claimants and the NHS, of settling most, if not all, high value personal injury claims, where future costs are significant." 66

Because of this general attitude, therefore, the indexation issue is of particular importance to the NHS. A second reason is that indexation affects a disproportionate number of clinical negligence cases because these are more likely to involve serious injuries when compared to the cases dealt with by liability insurers or other defendants. The high number of cases affected is illustrated by the fact that 104 NHS cases were stayed awaiting the Thompstone decision. These cases have now almost all been settled. Added to this backlog of PPO cases are those where claimants, as well as the NHS, now appreciate fully the additional benefits offered by the new method of settlement. It is therefore not surprising that the most recent figures from the NHS Litigation Authority show a substantial increase in the cumulative number of periodical payment cases: in the last three years they have risen from 471 in March

\footnotetext{
${ }^{65}$ R. Lewis, "Health Authorities and the Payment of Damages by Means of a Pension" (1993) Modern Law Rev $844-855$.

${ }^{66}$ NHSLA Report and Accounts 2009.
} 
2007 , to 548 in 2008, and to 659 in $2009 .{ }^{67}$ The current provision for all of these periodical payments amounts to $£ 1,373$ million.

Thompstone not only influences the extent that PPOs are used in NHS cases but also the amount of damages that are at stake. The NHS Litigation Authority has acknowledged that 2009 was a "challenging year" partly because Thompstone had made a "significant impact" upon the amount that it had to pay in settlements. This is illustrated by the overall increase in the cost of serious injury claims: the size of the average claim over a $£ 1$ million rose by more than a third, increasing by $£ 1$ million to $£ 3.7$ million. ${ }^{68}$ This higher cost per claim partly accounted for the 22 per cent rise in the cost of all claims made against the NHS in the last year: the total sum rose from $£ 661$ million to $£ 807$ million. In part this was due to an unusual and unexplained 11 per cent rise in the number rather than the value of claims. ${ }^{69}$ However, the increasing cost per claim was also a major factor, and it was Thompstone that largely accounted for the increase in the cost of long term care cases. Anticipating a further rise in overall costs, the Authority announced that premiums had risen by 53 per cent from $£ 467$ million to $£ 713$ million. Again this was partly due to the Court of Appeal decision. Overall it is clear that Thompstone has already had a major impact upon the cost of NHS litigation.

\section{THE LIMITS OF PERIODICAL PAYMENTS}

Although the precise scope for using PPOs subject to the new indexing provisions has not been finally determined, all parties now accept that they will become an increasingly important feature of settlement negotiations and personal injury awards.

${ }^{67}$ Ibid.

${ }^{68}$ [2008] Health Service J (23 December).

${ }^{69}$ This goes against the recent trend of decreasing numbers of claims. See generally, R. Lewis, A. Morris and K. Oliphant, "Tort Personal Injury Claims Statistics: Is there a Compensation Culture in the United Kingdom?” (2006) 14 (2) Torts LJ 158 - 175. The Chief Executive of the NHSLA has acknowledged that the Authority's figures "give the lie to any suggestion of a burgeoning compensation culture; it really just isn't happening in the NHS." S. Walker, "Have We Won?" (2008) 78 MedicoLegal $\mathrm{J} 3$ at 6 . 
However, lump sums will continue to be the form in which the vast majority of claims will be compensated. Why is this so and what limits the potential use of PPOs?

The most important factor is that PPOs can only be imposed if there is future loss; past losses or non-pecuniary loss can only form a part of the Order if the parties agree. Future loss is unusual, only occurring in about 1 in 14 personal injury cases. ${ }^{70}$ This is because the vast majority of claims are for minor injury where there are no continuing ill-effects and where the average payment is for but a few thousand pounds. In such cases a lump sum is obviously the most efficient and fairest way of disposing of the claim.

Even where the losses are severe and the damages are substantial a PPO can be avoided by the parties if they settle out of court. By striking a deal a claimant can arrange for the payment to be in the form of a lump sum alone. It is then possible to avoid judicial involvement in the amount of capital to be received and the timing of payments. However, those representing claimants who want to take this course should ensure that they have explained fully the advantages of PPOs. Their clients must give informed consent to the alternative form of settlement being proposed. Even in such cases PPOs will very much affect the bargaining process: as explained elsewhere, the threat of burdening a defendant with continuing payments can be used to gain higher lump sum awards. ${ }^{71}$

When a future loss case comes to court there will still be instances of where a judge will consider it inappropriate to order periodical payments. For example, the flexibility offered by the lump sum will be an important factor where the claimant's care needs are extremely difficult to forecast and could vary considerably. ${ }^{72}$ Again, if the damages are insufficient to fund the periodical payments needed to meet the

\footnotetext{
${ }^{70}$ See the Pearson Report op cit above note 26 at 44 and table 107.

${ }^{71}$ R. Lewis, “The Politics and Economics of Tort Law: Judicially Imposed Periodical Payments of Damages" (2006) 69 Modern Law Rev 418 - 442, at 424 et seq.

72 This was the case where the claimant's dependence upon alcohol was in issue in Preston v City Electrical Factors Ltd [2009] EWHC 2907.
} 
claimant's current care costs then a lump sum will be preferred. ${ }^{73}$ This may happen where the damages have been reduced for contributory negligence, or where a settlement figure is compromised to allow for the difficulties of establishing liability in court. Particular problems could be caused where the claimant has obtained large interim lump sum payments. ${ }^{74}$ The need to purchase suitable accommodation is not always easily met from the capital available to the claimant, and judges could be persuaded that a PPO is then inappropriate. Finally, where security of payment is an issue and the defendant is unable to satisfy the judge that future payments are assured, a lump sum may be preferred. ${ }^{75}$

\section{CONCLUSION}

The new periodical payments regime introduced by the Courts Act 2005 is a major development in tort law. A real attempt has been made by the legislature to meet the future needs of claimants and thus move closer towards restorative justice. However, the key to the extent to which periodical payments will be used is the method by which they are to be indexed, and this was left for the courts to decide. It is not surprising that the case which determined this issue was selected by personal injury practitioners as the most important of its year. The Thompstone decision, although neglected by academics, is a landmark case in the law of tort. It goes a long way towards reassuring a few very seriously injured tort claimants that their future will be more secure.

${ }^{73}$ Rowe v Dolman [2008] EWCA Civ 1040.

${ }^{74}$ Eeles v Cobham Hire Services Ltd [2009] EWCA Civ 204, Johnson v Compton-Cooke [2009] EWHC 2582.

${ }^{75}$ In Okeowo v Norton, a case settled out of court in 2008 and noted by A. Plears in (2008) 158 New LJ 1247 , the liability insurer was a Lloyd's syndicate and thus was not "reasonably secure" within the meaning of the Damages Act 1996 s 2 (4) (b). However, the claimant accepted an annuity, bought from a secure life office, even though it was linked only to the RPI because it was also accompanied by $£ 1$ million lump sum to compensate for the lack of earnings indexation. 